The evolution of e-learning practices at the University of Tehran: A case study

\author{
Babak Sohrabi \\ University of Tehran, Tehran, Iran \\ Iman Raeesi Vanani \\ Allameh Tabataba'i University, Tehran, Iran \\ Hamideh Iraj \\ University of Melbourne, Melbourne, Australia
}

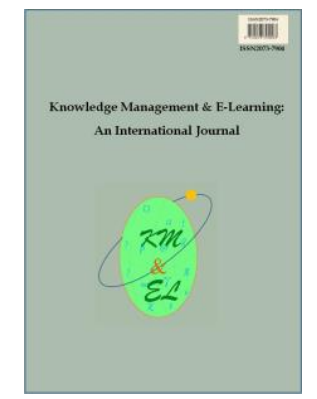

Knowledge Management \& E-Learning: An International Journal (KM\&EL) ISSN 2073-7904

Recommended citation:

Sohrabi, B., Vanani, I. R., \& Iraj, H. (2019). The evolution of e-learning practices at the University of Tehran: A case study. Knowledge Management \& E-Learning, 11(1), 20-37. https://doi.org/10.34105/j.kmel.2019.11.002 


\title{
The evolution of e-learning practices at the University of Tehran: A case study
}

\author{
Babak Sohrabi* \\ Faculty of Management \\ University of Tehran, Tehran, Iran \\ E-mail: bsohrabi@ut.ac.ir
}

\section{Iman Raeesi Vanani}

Faculty of Management and Accounting

Allameh Tabataba'i University, Tehran, Iran

E-mail: imanraeesi@atu.ac.ir

\section{Hamideh Iraj}

Faculty of Management

University of Melbourne, Melbourne, Australia

E-mail: hiraji@unimelborn.edut.au

*Corresponding author

\begin{abstract}
Learning is a new educational paradigm in the age of information technology. These days, most universities worldwide consider e-learning as a strategic asset to make education accessible to everyone. The current paper evaluates the e-learning programs at the University of Tehran from an organizational point of view, and seeks to realize how it evolved over time and adapted to the changing environment. Using a qualitative method, this study draws a comprehensive picture of e-learning events and challenges in different phases, as well as their impacts in multiple aspects. The evolution also shows a gradual decentralization in the administration processes and the transformed elearning programs from a standalone effort into teamwork at the enterprise level.
\end{abstract}

Keywords: e-Learning; Organizational aspects; Business models; Administration; Evolution

Biographical notes: Babak Sohrabi is a Professor in the Department of Information Technology Management, Faculty of Management at University of Tehran, Iran. He received his $\mathrm{PhD}$ in Management Science, from Lancaster University in England. He is the Editor-in-Chief of the Information Technology Management Journal. His research interests include artificial intelligence, knowledge management, E-Learning, decision support systems and organizational impact of information technology. His research has appeared in the Journal of Interdisciplinary Mathematics, International Journal of Engineering, Journal of Operational Research Society, International Journal of Production Research, Computers \& Industrial Engineering, Review of Business Information Systems, Applied Soft Computing, International Journal of Engineering, International Journal of e-Collaboration, Expert System with Applications, International Journal of Applied Industrial Engineering, 


\begin{abstract}
International Journal of Management \& Enterprise Development, Behavior and information technology, international Journal of Hospitality Management International, Computers in Human Behavior, scientometrics, Journal of Human Sciences.

Iman Raeesi Vanani is a PhD Graduate in Systems Management, School of Management, University of Tehran. He is currently an assistant professor in Allameh Tabataba'i University. He received his MSc in Information Technology Management from School of Management, University of Tehran and his BA in Public Administration from Allameh Tabataba'i University. His research interests include Data Science, Advanced Analytics, Business Intelligence, Data Mining, Enterprise Resource Planning, and Big Data Management. He has published many conceptual and practical research papers in various international journals, conference proceedings, and books including International Journal of Hospitality Management, Neural Computing and Applications, The IUP Journal of Knowledge Management, Intelligent Engineering Informatics, Iranian Management Vision Journal, Iranian Journal of Science and Technology Policy, Journal of Information Technology and Sciences, Information Science Reference publications, and other international and Iranian journals, Books and conferences.
\end{abstract}

Hamidh Iraj is a doctoral candidate of Faculty of Management, The University of Melbourne. Her research interests include data mining, E-Learning. Her research has appeared in Computers in Human Behavior journal, scientometrics.

\title{
1. Introduction
}

The advent of new technologies and their use in education is changing the modes of learning. In a rapidly changing world each country tends to restructure its own education system using various technologies available today (Harun Can, 2015). The web-based electronic learning (e-learning) has played an important role in teaching and learning, which becomes more and more popular not only at different levels of schools but also in various adult education institutions around the world (Nedungadi \& Raman, 2012). eLearning has fewer restrictions in learning process that students can learn at any time and in any place (Goda et al., 2015). With the development of e-learning, there are more and more educators being committed to the development of on-line courses (Castillo-Merino \& Serradell-Lopez, 2014).

e-Learning is a young and groundbreaking phenomenon for serving the needs of learners. Universities use the e-learning as a method of establishing formal education programs leading to degrees, professional training such as certificate and industryspecific courses (sometimes referred as non-matriculated programs). The corporate training market uses the e-Learning as a method of teaching for industry professionals. It has also widened its scope to the informal education, such as Massive Open Online Courses (MOOCs). As a matter of fact, the use of technology and new communication channels allow both teachers and learners to experience a social, interactive and vibrant learning environment. The role of governments cannot be ignored in this respect as they invest in e-learning initiatives in order to make education accessible to everyone by lowering the barriers of time and place and providing flexibility and affordability especially for those who could not enter traditional programs (Bichsel, 2013). 
In a recent survey (Allen \& Seaman, 2014), the number of academic officers considering online education as a critical component to their long-term strategy has increased from $50 \%$ in 2002 to about $70 \%$ in 2012 but dropped to $65 \%$ in 2013 due to institutions without online offering as stated in the report. According to Global Industry Analysts Inc. (2016), the global e-learning market is expected to reach $\$ 241$ billion by 2022. This rise is attributed to the increasing use of HTML5 based browsers, cloud computing, smart mobile devices and strong penetration of broadband Internet. Furthermore, research firm TechNavio (2014) estimates that the global e-learning market will post a compound annual growth rate of $15.06 \%$ for the period $2015 \mathrm{e} 2019$. Another wide-scale study conducted by Ambient Insight (2014) for 106 countries has revealed that the worldwide market for self-paced e-learning has reached $\$ 42.7$ billion in 2013; the five-year compound annual growth rate is $4.4 \%$, and revenues are expected to reach $\$ 53$ billion by 2018 . There are also many companies which have established education and learning centers and provide practical skill-based courses for participants (Kimiloglu, Ozturan, \& Kutlu, 2017).

In the traditional transfer learning model, the teacher serves as the repository and transmitter of knowledge however. With MOOCs the teaching method is inverted by using the flipped classroom model where the learner interacts with peers, and has flexible access to information and resources around him before coming to classroom. The learning cycle is an ongoing process that is designed to improve the quality of learning as well as the collaboration among learners (Brahimi \& Sarirete, 2015).

However, the borders of these e-learning related concepts are blurry and many instructors and researchers often attempt to use the best practices of each category to the other. Over the years, some formal e-learning courses turned out to be successful online certificate programs. Also, some universities hold MOOCs for the course credit. In other words, e-learning practices are growing rapidly in quantity and diversity and this, in turn, adds to the richness of the existing knowledge about the topic.

Iran is a country in the Middle East with more than 77 million populations and an internet penetration rate of 57.2 percent (Internet Usage in the Middle East, 2016). The country known as cradle of ancient civilization today largely contains young people with roughly one-third of the population aged 25-40 (Young population a golden opportunity, 2014). Here, the importance of having formal university degrees in the job market went up both in public and private sectors hence; it made higher education a necessity for employment and promotion. Further, the degree inflation is evident as having a university degree that became a prerequisite for jobs did not require anymore. On job seekers' side, many young Iranians especially in urban areas and people with middle to high income levels still consider entering universities. Gender balance and language are other interesting characteristics. The number of female students exceeded the male in recent years (Harrison, 2006). The teaching language of all programs is Persian. Considering all these points, Iran has a unique stand in the area, making it distinct from other countries. These also make studying the e-learning in Iran interesting and worthwhile.

The University of Tehran was founded in 1934 as the first modern university in Iran. It is the best comprehensive research university in engineering, sciences, agriculture and environmental science, art, humanities and social sciences. The University of Tehran, as a public institution receives a considerable amount of budget from the government (UT at a Glance, 2016). It has more than 19,000 undergraduate and 13,000 graduate students, 39 faculties and 120 departments at its eight campuses across the country. There are more than 2150 faculty members, 55 research centers, 550 labs and 80 scientific journals active in theoretical and practical researches (Facts and Figures, 2016). 
The E-Learning Center at the University of Tehran was established in 2002 under the supervision of the academic vice-president. Establishing the center was the result of the university commitment to expand quality education, promote the brand of the university and play a big role in e-learning beside the traditional education in Iran. These are similar to the reasons Bates offered for ICT integration in universities (Bates, 2000, pp. 35-40). The center started with 70 students and grew exponentially in number and diversity of programs and hence, turned into the largest e-learning center in the country. The University of Tehran paid special attention to the e-learning in its five-year strategic plan (2011-2015) with its target to have 15 percent of all credit courses in this field by the end of 2015 (University of Tehran Second Plan, 2011).

The main goal of the E-Learning Center is to guide the university transform elearning and help in setting strategic goals, policy making, planning and control. In addition, the E-Learning Center as a centralized IT department provides the infrastructure (including the LMS and studio-type instructional rooms), technical and operational support for online programs at the enterprise level. It also helps instructors in instructional design issues. The center offers online two-year master's programs. The elearning students' demographics are different from rest of the campus students. The ratio of working and married students is higher than campus-based students. The age of elearning students is also higher both in its mean and standard deviation.

Integrating e-learning in higher education has different aspects. This paper tries to study e-learning from an organizational point of view and discusses the change in administration, business model and procedures that could make e-learning a successful practice at the University of Tehran.

\section{Review of the literature}

\section{1. e-Learning practices}

Learning is a long-term process; the outcomes are perceived only after students have invested significant amounts of time and effort. The ability to sustain interest, and invest hard work over extended periods of time, varies significantly from individual to individual. The impact of momentary failure in this investment also varies considerably in students. Successful students often taste failure, but they also know that perseverance and constant effort lead to their goals. Studies demonstrate that even if students pursue long-term goals, they reveal different performances due to individual psychological characteristics (Aparicio, Bacao \& Oliveira, 2017).

Many researchers have already studied the impact of e-learning from different perspectives, including the paradigm shift and pedagogical point of view. They explained the ever-increasing technological changes and the way technology is changing our lives: from our communication and working styles to how we learn and what we expect from a formal learning environment (Anderson \& Elloumi, 2004, p. 3; Ossiannilsson, 2012; Miller et al., 2013, pp. 14-15).

Studies revealed that active learning strategies increase students' participation in the learning environment and improved learning process and results (Freeman et al., 2014; Yilmaz \& Keser, 2016). From another point of view, for the active learning to take place, there is a need for a continuous motivation (Yilmaz, 2017). Motivation towards elearning, a component of readiness for e-learning, is defined as the desire and 
refreshment state having physical, cognitive and affective components inside and prompting people to do things for e-learning (Demir, 2015).

Uysal and Kosemen (2013) state that individual motivation, feelings, ideas and behaviors are among the constructs that self-efficacy belief effects. As a result, it is believed that e-learning readiness of the learners is an important predictor of motivation in the classes. Kuo, Walker, Schroder, and Belland (2014) found in their online learning study that learners' internet self-efficacy, self-regulated learning, learner-learner interaction, learner-instructor interaction, and learner-content interaction were interrelated with their satisfaction.

\section{2. e-Learning business models}

According to Powell (2011) e-Learning means education in which instruction and content are delivered primarily via the Internet. According to Al-Qahtani and Higgins (2012), when traditional education and eLearning education are dealt with same topics the result of eLearning are better than what is achieved through the traditional F2F education. Abrami et al. (2006) stated that eLearning in Canada is more effective than traditional F2F education. It provides quick and easy access to education. e-Learning is suitable for students who may have problem with their learning abilities. Despite an ever-increasing spread of e-learning, only a few managerial aspects of e-learning could be studied such as business strategies, business models and best practices (Vignare, Geith, \& Schiffman, 2006; Smith, Smith, Samors, \& Mayadas, 2008).

A business model is defined as the flow of products, services and information all in one architecture, different business actors, their roles and potential benefits and sources of revenues by Timmerman, cited in (Hoppe \& Breitner, 2004). As the definition implies, a business model describes a business enterprise/sector holistically and gives an idea of how different actors and their interactions create value and how the value translates into products and services for customers. For the evaluation of e-learning results, some of the studies have used the information systems success models like the DeLone and McLean IS success model in the e-learning context (Aparicio, Bacao \& Oliveira, 2016; Mohammadi, 2015).

In this paper, the researchers consider two meanings for the term "business model". The first implies the framework in which e-learning products, services and information flows are defined between the University of Tehran and entities outside the university. In the framework, the brand of the university makes it attractive for other organizations. This aspect has been investigated by many researchers such as (Hoppe \& Breitner, 2004; Mendling, Neumann, Pinterits, Simon, \& Wild, 2005; Henninger, Kutter, Jaschniok, Schmidt, \& Barth, 2010).

The second meaning is the circulation of tuition revenue inside the university i.e. the flow of revenue among the university central office, the E-Learning center and the departments. To make the second meaning more plausible, the current paper refers it as "internal business model". Here, the brand of the university has no role and only the circulation of income matters.

\section{3. e-Learning organizational structure}

e-Learning organizational structure deals with e-learning services, how they are organized and structured and whether they are delivered in a centralized or decentralized way. The organizational structure model plays an important role in e-learning integration 
in universities. With respect to the academic affair, universities are traditionally decentralized but they are centralized in administration and support services (Miller et al., 2013 , p. 17). But it must be remembered that none of the administrative methods fits all institutions. The issue is a trade-off between control/centralization and freedom/decentralization hence the desirable administrative method depends on goals, values and priorities of an institution (Anderson \& Elloumi, 2004, p. 103).

Previous researchers recommended centralized LMS and technology services to avoid confusion for users and improve their learning curve (Kucina Softic \& Bekic, 2008). They emphasized on a dedicated center for e-learning services as a key part of an e-learning program. However, universities owning an e-learning center are more likely to be serious and mature in their practices. In Korean higher education, universities with more than 10,000 students were more likely to have an e-learning center than those with less than 10,000 students (Leem \& Lim, 2007). It is evident that the university considers e-learning as a strategic unit of the institution and committed to developing and supporting the e-learning programs.

On the other hand, the university departments design e-learning programs similar to the traditional ones. This gives the e-learning programs legitimacy and holds the faculty members responsible for quality control and keeping the standards (McCarthy \& Samors, 2009).

\subsection{Massive open online courses (MOOCs)}

The history of MOOCS is relatively new, but this phenomenon quickly spread all over the world and is being implemented in many countries. The first MOOC emerged from the open educational resources (OER) and was first used by Dave Cormier and Bryan Alexander (Willey, 2013). Educators may agree or disagree with MOOCs replacing traditional courses for a number of reasons (Brahimi \& Sarirete, 2014). Some say they are the future of higher education while others see them as downfall of it as reported by Nathan Heller's in The New Yorker (Peterson, 2017).

The emergence of MOOCs with their specific typology and platforms has necessitated an evaluation of their achievements and the possibilities for their integration into traditional educational systems (Lerís, Sein-Echaluce, Hern_andez, \& Bueno, 2017). The NMC Horizon Report of 2015 (Johnson, Adams Becker, Estrada, \& Freeman, 2015) includes MOOCs among the competing models of education as a 'wicked challenge', namely as being among 'Those that are complex to even define, much less address'. Many authors express opposing opinions regarding the value of MOOC training, whether as an opportunity for the dissemination of knowledge or in relation to its effects on preparation for the labour market (Raposo-Rivas, Martínez-Figueira, \& Sarmiento Campos, 2015; Zapata-Ros, 2013; Chiappe Laverde, Hine, \& Martínez Silva, 2015; Johnson et al., 2015). MOOCs are also considered tools for the dissemination of educational innovation and for the international visualization of educational institutions (Teixeira, Garcia-Cabot, García-Lop_ez, Mota, \& de-Marcos, 2016). MOOC's with no tuition also challenge the economic models of traditional universities and educational foundations.

Deming, Goldin, Katz, and Yuchtman (2015) found that institutions with more online students do charge lower prices. In addition, according to Christensen and Horn (2011), the development of online education such as MOOC will bring a "disruptive innovation", in which higher education will eventually become more convenient, accessible, and significantly cheaper. Some scholars believe that MOOCs will bring a 
revolution to, or even substitute, traditional high-cost education (Barber, Donnelly, \& Rizvi, 2013). In addition to the low cost, MOOC has the advantage of openness and flexibility, which challenges the closed and privileged nature of the traditional higher education (Krause \& Lowe, 2014). Individuals now have better access to education without the limit of geography, time, and financial constraints. As a result, MOOC is especially important for lifelong learners and working professionals who have a high opportunity cost of time (Schuwer et al., 2015).

\section{5. e-Learning at University of Tehran}

Several previous studies have already investigated e-learning at the University of Tehran. Researchers in different departments described the e-learning programs in their own fields, including entrepreneurship (Jafari Moghadam, Zaefarian, \& Salamzadeh, 2012; Radovic Markovic, Salamzadeh, Markovic, Grozdanic, \& Vucekovic, 2012) and agriculture (Talebian, Movahed Mohammadi, \& Rezvanfar, 2014). Moeini, Kiani, and Mohajerani (2003) studied pedagogical, cultural and organizational challenges in the early days of University of Tehran E-Learning center. The work of (Ketabchi, Mortazavi, \& Moeini, 2008) is about the user satisfaction of e-learning in the time when the center ran only a few e-learning courses. Since, the E-Learning Center changed dramatically over the years, the researchers of the current study decided to make a thorough investigation into the evolution of the e-learning practices at the university level.

\section{Research method}

\subsection{Research design}

Organizational aspects of e-learning are one of the practical yet under-researched topics in higher education. The researchers focused on this aspect of e-learning at the University of Tehran by addressing the following research questions:

1. How have the e-learning implementation practices at University of Tehran evolved over time? How has the administration and/or business model changed?

2. How have the university, the students and the society benefited from e-learning programs?

3. How has the E-Learning Center dealt with challenges using relevant solutions?

The researchers had an interpretivist paradigm in mind because the change in elearning practices is inherently subjective, so only qualitative research methods could help in answering the research questions. The research was conducted using a qualitative single-case study. A case study sheds light on a set of decisions such as why these decisions were made and what the results were? The researchers preferred this method considering that universities function in the context of their country and culture, thus, their behaviors cannot be manipulated and interpreted neglecting their environment. The method also allows the researchers to study unique features of e-learning at the University of Tehran and seek a holistic and meaningful narrative of the contemporary events. A single case study allowed the researchers to delve deeper into the case and focus on the details and nuances of the decision-making process and results (Yin, 2003, p. $39)$. 
The case in the current study is the E-Learning Center so the relevant topics to the center are explored, including the relationship with the university's central office, departments and instructors. Pedagogical issues such as teaching methods were excluded.

\subsection{Data collection}

In the current study, multiple data sources were considered for increasing the overall quality of the results. In other words, the data collection started by searching for relevant documents. The researchers found the university strategic plan, internal reports and statistics and the information available on the E-Learning Center website. For that matter, they studied the documents thoroughly to have a basic idea for the later phases of the research project. In due process, the researchers recorded the semi-structured interviews and took notes for verification and review purposes.

Interviewees were chosen using the judgmental sampling technique. The researchers selected staff and instructors who were immersed in e-learning. Participants are those who had taught courses and those who had received support with course design and technical issues. In other words, the participants have had a deep understanding of changes in the E-Learning Center and were able to answer the questions in a meaningful and rich way. There were 15 interviewees including the head of the e-learning center (with eight years of experience), four university vice-presidents and 10 educational managers belonging to different departments.

Each interview started by explaining the topic of research to the interviewee to ensure a basic understanding of the importance of the research and continued for 30-60 minutes. Each interview had five open-ended questions accompanied by the questions that emerged during the interview. As expected of a semi-structured interview, the participants were encouraged to express their experiences openly while answering questions.

The researchers arranged a focus group of five to triangulate the data collected from the interviews. The focus group participants confirmed the ideas extracted from individual interviews and helped the researchers interpret the results. This was very helpful because the e-learning program is a multi-dimensional and the current research needed the views of different stakeholders.

\subsection{Data analysis}

After the interviews were done and notes were verified by the interviewees, the researchers started investigating their notes, classifying them and assigning them to the research questions. Further queries arose while the researchers were interpreting the interview results hence; they made additional phone calls to the participants to get clarifications. Additionally, interview findings were compared with relevant documents to find inconsistencies and conflicts and solve them iteratively. A textual analysis related notes to research questions. After coding the notes several times and finding the themes, they were associated with the research questions and were interpreted.

\section{Results}

The researchers observed an interesting pattern among the answers to the research questions. Three phases that emerged during the data analysis described the development 
at the E-Learning Center. The researchers decided to consider the three questions dependent and answer the second and third within these three phases. This approach helps the researchers and readers of this paper to better classify and understand the flow of events.

\section{1. e-Learning development phases}

The three phases were named inception, growth and maturity which were the outcome of clustering the events. As indicated by the labels, during each of the phases, the main concern of the E-Learning Center differed. The details of each phase accompanied by challenges and solutions are discussed below.

The First Phase: Inception. The first phase was in the 2002-2007 time interval. The center started as a centralized unit, quite independent of university departments. It was responsible for students' admission, enrollment, running the programs and graduation, regardless of the department the program belonged to. For teaching purposes, the center signed a contract with instructors from different departments and paid them based on a fixed credit-hour wage.

The Second Phase: Growth. The second phase started from 2007 and ended in 2013. The distinctive event in this phase was gradual decentralization. As the number of students and courses grew exponentially, the center realized that the centralized model is inefficient and decided to transfer some of the tasks to the departments. For instance, the center transferred enrollment and graduation tasks to the corresponding faculty registrar offices. Since they were already responsible for these types of works, they could do the same for e-learning students.

The results were better than expected; the departments embraced the change quickly. They were satisfied with the autonomy and felt responsible for providing highquality programs. The change allowed the university to have the e-learning programs at scale. In addition, students too gained the feeling of being treated equally with campusbased students and hence; thrilled by the decentralization.

The internal business model i.e. the revenue distribution changed during this period as well. In the centralized model, a considerable amount of revenue went to the ELearning center and the university central office. After decentralization, a large proportion of the revenue went to university departments.

In parallel to the gradual decentralization, the number of full-time employees in the center dropped by 75 percent. The decline evinced that the center was successful in integrating e-learning in university procedures and guided departments to do the job quite independently.

During this period, the center started to create the e-learning content for later reuse. Since, the creation of high-quality courses was time-consuming and expensive, reusing learning materials found to be the cost-cutting methods for e-learning programs (Marshall, 2007). On the other hand, traditional university professors (who were used to teach solely in face to face classes) lacked expertise in creating online courses and needed help in instructional design. As such, the E-Learning Center held workshops to train the instructors. Later these workshops became mandatory to make sure the instructors receive the training they needed.

To motivate the instructors, the center paid them to create the content. However, this effort failed as instructors refused to teach the contents created by somebody else and were inclined to teach self-prepared material. This way, they could earn by selling their 
content to the center. Authors could also benefit from selling their textbooks to a large number of students in an online course.

The Third Phase: Maturity. The third phase started from 2013 and continues until today. The number of students raised from a few hundred to thousands of students being taught and graduated. This phase started when the operational tasks have already been transferred to corresponding departments and the center limited its activities to policymaking, planning, control and technical support. The E-Learning Center was mature and efficient so it started to extend its activities outside the university boundaries.

Having the required infrastructure and experience and holding the brand of the university, the center started to offer e-learning services to organizations and entered the corporate training market. The center offered an all-in-one solution, as defined in (Hoppe \& Breitner, 2004), including e-learning application, hardware and infrastructure and elearning services such as technical support. It was a successful practice. Instead of building an e-learning infrastructure from scratch, companies benefited from an up and running service. Unlike advertising and sponsorship business models in (Mendling et al., 2005), the e-learning as a service does not interfere with students' learning experience. In addition, the model brings sustainable revenue for the university (Hoppe \& Breitner, 2004).

\section{2. e-Learning benefits}

Answering the second research question, the e-learning development had the following tangible benefits:

- $\quad$ Revenue for the university: The university degrees demand in Iran is very high. Therefore, the University of Tehran as a public institution stepped into fulfilling this demand and making money.

- Affordability for students: e-Learning programs are an affordable way for students to get the university degrees. The cost of an e-learning program is roughly half of a campus-based program in private universities (such as Islamic Azad University).

- Flexibility: Electronic classes are flexible for both students and instructors, allowing them to attend a class regardless of place constraints. This, in turn, attracts many working students in pursuing a degree program without losing their jobs.

- Access to professors who work abroad: Using electronic classes, the University of Tehran could employ professors living abroad hence; a new channel for communication and knowledge sharing came into existence.

- Higher enrollment for International Students: The e-learning infrastructure allowed foreign students to pursue a degree at the University of Tehran. This is important because the number of foreign students in Iran is limited thus by higher enrollment, the e-learning programs can enhance the university brand and elevate its place and ranking internationally.

- Enhancing work commitment: Recording lectures make professors more sensitive to their teaching style and course contents because these recordings are downloaded by students after the class and are monitored by the E-Learning Center. 
These changes in e-learning practices had produced the following byproducts for enriching traditional teaching and learning.

- $\quad$ Blended Learning. The spread of electronic courses helped introduce the concept of blended learning. Students and instructors in face-to-face classes used the LMS for file sharing, question and answer and other forms of knowledge sharing.

- Computer and Internet Literacy. The use of e-learning and blended learning improved the computer and internet literacy among the instructors and students especially those who were unskillful such as instructors and students with Humanities background.

- $\quad$ Lecture Recording. Some classes needed face-to-face sessions for teaching and question and answer. The center decided to record these sessions using smart boards to allow all students (campus-based and e-learning) use the content. This effort was welcomed since it provided an equal learning opportunity for the on campus and E-Learning students.

- $\quad$ Corporate Training. As mentioned, the center started to give e-learning service to other organizations. Meeting the needs of such organizations brought revenue to the university.

- Online Thesis Defense. Campus-based students used the online system while defending their theses especially when one thesis supervisor was abroad on a sabbatical leave. The online infrastructure allowed the students to defend and graduate on time and prevented student frustration.

- $\quad$ Online Quizzes. Instructors of both traditional and e-learning classes used online quizzes in their courses. A question and answer database were the source and questions were chosen randomly from the database. This brought in scalability and provided quantitative feedback for the instructors.

\subsection{Administration challenges}

The E-Learning center used different methods to solve the challenges of each phase.

There were many challenges during the Inception Phase.

- Challenge 1.1: Introducing e-learning as a valid method of education to the society. In the beginning, there were a lot of questions and doubts about elearning. Students were unsure how the society would react to their degrees: Will universities and companies treat them as equal to campus-based students? Is it prestigious to attend an e-learning program? The challenge corresponds to "social character" and "reputed universities" in (Moeini, Kiani, \& Mohajerani, 2003). From the university side, senior managers were doubtful to enter the elearning market or not. The reputation of the university and starting e-learning programs -considered an inferior form of education at the time- seemed contradictory.

- Challenge 1.2: Because of low and unstable internet bandwidth in Iran, many students were doubtful if the e-learning works in practice. They were worried that they may be unable to access the courses with the low-speed internet.

- Challenge 1.3: Traditional university professors were reluctant to teach electronic classes because they were unwilling to step out of their comfort zones and deal with pedagogical and technological issues. To overcome this challenge, the center offered higher wage per credit hour for online instructors. 
- $\quad$ Challenge 1.4: The center had to find the right tools (including the LMS) to hold the first e-learning classes.

The decentralized model had several disadvantages.

- Challenge 1.5: A heavy workload of tasks in the center made it practically inefficient.

- Challenge 1.6: The decentralized model made departments indifferent to the challenges faced by the center which made the collaboration difficult.

- Challenge 1.7: The university departments had no financial benefit from elearning activities. On the other hand, they had to allocate instructors to the elearning programs. As a result, it was a matter of conflict and tension between departments and the E-Learning Center.

- Challenge 1.8: A great amount of dissatisfaction existed among students because they were served solely by the E-Learning Center, lacked the sense of connectedness to university departments and felt isolated from the on-campus students.

Challenges 1.1 to 1.3 were the most difficult ones to deal with. At the time of enrollment s, there were a huge amount of phone calls to the center asking for information for deciding to enroll or not. Many students had no idea of e-learning: some of them might mistakenly confuse it with distance education, many new students were wondering if they should attend classes or not. How do their exams and presentations look like? How is it like to be an e-learning student? The challenges still exist but public opinions changed gradually as more students graduated.

Challenge 1.4 was a technological one. The center experimented with different tools to find the right one that served the needs of the classes. Characteristics of the LMS including its concurrency, speed and user-friendliness were tested to check its suitability for further use (Ketabchi, Mortazavi, \& Moeini, 2008).

Challenges 1.5 to 1.8 were gradually vanished as the decentralization went further. In fact, that was the main reason that pushed the E-Learning Center to the decentralized model.

The Growth Phase had the following challenges.

- $\quad$ Challenge 2.1: Inadequate faculty members for teaching the courses

- Challenge 2.2: Inadequate faculty members for supervising the students' theses

- Challenge 2.3: Heavy workload for instructors due to a large number of courses and students.

- $\quad$ Challenge 2.4: The sense of loneliness for students due to a large number of students in a class.

Challenges 2.1 and 2.2 were serious. The number of enrolled students was growing rapidly and there were insufficient faculty members for teaching and supervising. For teaching purposes, the E-Learning Center hired adjunct professors and faculty members from other campuses/universities to respond to the demand. The center also started negotiating with Iranian university professors at foreign universities (and could teach in Persian) and prominent Ph.D. students to meet the high demand. 
However, the center needed to apply some other solutions for supervising the theses keeping in mind that most of the e-learning students' study at master's level. The center decided to design these e-learning programs as taught-only and removed the by research option from the programs.

This solution created another challenge: the popularity of the programs declined because the e-learning master's degree without the research component could not lead to a Ph.D. The center decided to put in the research component for a limited number of the best students and leave the other degrees as taught-only. On the other hand, students of taught-only programs were working students. They complained that too theoretical courses do not help them in developing the required skills for the industry.

Resolving the challenge 2.3 , the center started to recruit teaching assistants to help the instructors in instructional design and answering to students' questions. In addition, one to one technical support for the instructors were practically impossible in this phase due to a large number of courses running on a daily basis. For guiding instructors and troubleshooting technical problems, the center dedicated a technical teaching assistant to every instructor, sitting beside the instructor in every course to solve problems immediately. This activity helped the instructors to mitigate the fear of technology and demonstrated the high commitment the center had for alleviating barriers to effective teaching and learning.

Resolving the challenge 2.4, for helping students in connecting to their peers, the center designed and implemented a social network which allowed them to expand their networks. The University of Tehran social network is accessible to students and graduates of all levels. It has more than 8000 users and continues to grow. It was useful, especially for the e-learning students who could not meet regularly.

The Maturity Phase has the following challenges.

- $\quad$ Challenge 3.1: Working with companies required rules and regulations to guide contracts. In the absence of such rules and regulations, the center had to spend the time to write those firms and get an approval from the University of Tehran.

- Challenge 3.2: The "E-Learning as a service" model was new for the ELearning center and even for the university. As a result, new topics emerged during this phase such as defining services offered by the center, designing service level agreements, negotiation and issuing contracts. None of these activities were typical of a university center activity so far. Therefore, the center appealed to experts for doing the job for the first time at the university level.

Resolving the 3.1 and 3.2 challenges, the center wrote the rules and guidelines and ran the "E-Learning as a service" model with the help of external consultants. The researchers find this challenge to continue because offering services to other organizations require continuous improvement in products and services and competing with the rivals, similar to a for-profit company. This gives the E-Learning Center a typical roles and responsibilities and the center will gradually move away from its traditional roles.

\section{Discussion and conclusion}

Overall, the current paper could document the evolution of e-learning practices at the University of Tehran in three phases and discussed the characteristics, challenges and solutions of each phase. The three phases imply that a fixed organizational structure is 
inapplicable to different stages of developing e-learning programs. While the centralized model works best in the beginning, a gradual decentralization is necessary to integrate the e-learning programs in universities and bring it to scale. Scalability means meeting higher demand and bringing higher revenue for the university. e-Learning also frees university from the shortage of on-campus space, crowded classrooms and shortage of faculty members.

The three phases discovered in the current study correspond to the ICT integration pyramid in university as mentioned in (Morer, 2008, p. 471). The inception, growth and maturity phases correspond to "technological need", "the need for management improvement" and "the need for widening and improvement of teaching and learning". Looking from the two perspectives, a university journey to e-learning is based on phases and going to a later phase (or going up in the pyramid) shows a greater advancement and maturity in the organization.

Implementing e-learning at the University of Tehran had tangible benefits. Many of them were mentioned frequently in the literature, including revenue generation (Vignare, Geith, \& Schiffman, 2006; Bichsel, 2013), affordability (Bichsel, 2013), flexibility (Smith, Smith, Samors, \& Mayadas, 2008; Morer, 2008, p. 457; Bichsel, 2013) and improved IT infrastructure at the university level (Smith, Smith, Samors, \& Mayadas, 2008).

Among the rest, employing Iranian instructors from foreign universities is a big advantage. e-Learning works as a non-trivial channel for knowledge creation and sharing; instructors can transfer their knowledge and skills to e-learning students to tighten the knowledge gap between the developed and the developing countries. The researchers predict that this collaboration can enhance the quality of the programs and lead to higher satisfaction among students.

However, the e-learning programs in Iran did not have a relationship with industry and failed to offer practical skills in their programs. Many e-learning students are working professionals who continue their study to gain new skills and enhance their career. By doing so, the University of Tehran meets the demand of working students and educates the next generation of industry professionals.

Several challenges and solutions were raised in the results section of this paper. Beyond the aforementioned topics, the researchers found underlying concepts: customization and tailoring. The idea covers many challenges of the e-learning programs. In the context of this paper, e-learning students are different from traditional students in their demographics, skills and expectations. Therefore, the university must see them as a different population with specific needs. Refusing to do so will be a strategic mistake and may hinder the sustainable growth of the e-learning programs.

For instance, in the case of dissatisfaction and frustration, students drop out of elearning programs sooner than their campus-based peers because many of them have fulltime jobs and struggle to study and work simultaneously so they will drop an inefficient program that takes their time and does not enhance their career. Some working students have a career plan for themselves (keeping in mind that the center has only master's degree programs). They finish a program only if it helps in their plans. They expect a cost-effective, flexible and customizable program that creates a tipping point in their professional lives and remains as a successful learning experience. 


\section{ORCID}

Babak Sohrabi (iD https://orcid.org/0000-0001-6188-2607

Iman Raeesi Vanani (D) https://orcid.org/0000-0001-8324-9896

Hamideh Iraj (iD https://orcid.org/0000-0002-7831-9324

\section{References}

Abrami, P., Bernard, R., Wade, A., Schmid, R., Borokhovski, E., Tamin, R., ... Peretiatkowicz, A. (2006). A review of eLearning in Canada: A rough sketch of the evidence, gaps and promising directions. Canadian Journal of Learning and Technology, 32(3): 1.

Allen, I. E., \& Seaman, J. (2014). Grade change: Tracking online education in the United States. Retrieved from http://www.onlinelearningsurvey.com/reports/gradechange.pdf

Al-Qahtani, A. A. Y., \& Higgins, S. E. (2012). Effects of traditional, blended and eLearning on students' achievement in higher education. Journal of Computer Assisted Learning, 29(3), 200-234.

Ambient Insight. (2014). The 2013-2018 worldwide self-paced e-learning market. Retrieved from http://www.ambientinsight.com/Reports/eLearning.aspx

Anderson, T., \& Elloumi, F. (2004). Theory and practice of online learning. Athabasca University. $\quad$ Retrieved from https://auspace.athabascau.ca/bitstream/handle/2149/411/?sequence $=1$

Aparicio, M., Bacao, F., \& Oliveira, T. (2016). Cultural impacts on e-learning systems' Success. The Internet and Higher Education, 31, 58-70.

Aparicio, M., Bacao, F., \& Oliveira, T., (2017). Grit in the path to e-learning success. Computers in Human Behavior, 66, 388-399.

Barber, M., Donnelly, K., \& Rizvi, S. (2013). An avalanche is coming: Higher education and the revolution ahead. London, UK: Institute for Public Policy Research.

Bates, A. W. (2000). Managing technological change. San Francisco, CA: Jossey-Bass.

Bichsel, J. (2013). The state of e-learning in higher education: An eye toward growth and increased access. EDUCAUSE Center for Analysis and Research.

Brahimi, T., \& Sarirete, A. (2014). Faculty attitudes towards MOOCs in higher education. Paper presented at Learning and Technology Conference. Jeddah, KSA: Effat University.

Brahimi, T., \& Sarirete, A. (2015). Learning outside the classroom through MOOCs. Computers in Human Behavior, 51(Part B), 604-609

Castillo-Merino, D., \& Serradell-Lopez, E. (2014). An analysis of the determinants of students' performance in e-learning. Computers in Human Behavior, 30, 476-484.

Chiappe Laverde, A., Hine, N., \& Martínez Silva, J. A. (2015). Literatura y practica: Una revisi_on crítica acerca de los MOOC. Comunicar, 44, 9-18.

Christensen, C., \& Horn, M. (2011). Colleges in crisis: Disruptive change comes to American higher education. Harvard Magazine. 7(21), 1-4.

Deming, D. J., Goldin, C., Katz, L. F., \& Yuchtman, N. (2015). Can online learning bend the higher education cost curve? American Economic Review, 105(5), 496-501.

Demir, O. (2015). The investigation of e-learning readiness of students and faculty members: Hacettepe university, faculty of education example. Master Thesis, Hacettepe University, Ankara, Turkey.

Facts and Figures. (2016). University of Tehran. Retrieved from http://ut.ac.ir/en/page/756/facts-and-figures

Freeman, S., Eddy, S. L., McDonough, M., Smith, M. K., Okoroafor, N., Jordt, H., \& 
Wenderoth, M. P. (2014). Active learning increases student performance in science, engineering, and mathematics. Proceedings of the National Academy of Sciences, 111(23), 8410-8415.

Global Industry Analysts Inc. (2016). MCP-4107: E-learning: A global strategic business report. Retrieved from http://www.strategyr.com/eLEARNING_Online_Education_Market_Report.asp

Goda, Y., Yamada, M., Kato, H., Matsuda, T., Saito, Y., \& Miyagawa, H. (2015). Procrastination and other learning behavioral types in e-learning and their relationship with learning outcomes. Learning and Individual Differences, 37, 72-80.

Harrison, F. (2006, September 19). Women graduates challenge Iran. BBC News. Retrieved from http://news.bbc.co.uk/1/hi/world/middle east/5359672.stm

Harun Can, M., (2015). An investigation of teacher's use of elearning in science Olympiad in Russian schools. Procedia - Social and Behavioral Sciences, 191, 241249.

Henninger, M., Kutter, A., Jaschniok, M., Schmidt, C. B., \& Barth, C. B. (2010). Business models for the new approach of "Focused E-Learning" at universities. Paper presented at American Educational Research Association (AERA) Annual Meeting. Denver, Colorado, USA.

Hoppe, G., \& Breitner, M. H. (2004). Sustainable business models for e-learning. IWI Discussion Paper Series, $7 . \quad$ Retrieved from http://www.immagic.com/eLibrary/ARCHIVES/GENERAL/UHANN_DE/H040107 H.pdf

Internet Usage in the Middle East. (2016, April 11). Internet World Stats. Retrieved from http://www.internetworldstats.com/stats5.htm

Jafari Moghadam, S., Zaefarian, R., \& Salamzadeh, A. (2012). Challenges of entrepreneurship e-education: Evidence from a developing country. In Proceeding of the Entrepreneurship Education - A Priority for the Higher Education Institutions. Retrieved from http://ssrn.com/abstract=2164221

Johnson, L., Adams Becker, S., Estrada, V., \& Freeman, A. (2015). NMC horizon report: 2015 higher education edition. Austin, Texas: The New Media Consortium. Retrieved from http://cdn.nmc.org/media/2015-nmc-horizon-report-HE-EN.pdf

Ketabchi, E., Mortazavi, M., \& Moeini, A. (2008). Evaluation of user satisfaction in center of eLearning-University of Tehran. In Proceedings of the International Conference on Computer Science and Software Engineering (pp. 536-539).

Kimiloglu, H., Ozturan, M., \& Kutlu, B. (2017). Perceptions about and attitude toward the usage of e-learning in corporate training. Computers in Human Behavior, 72, 339349.

Krause, S. D., \& Lowe, C. (2014). Invasion of the MOOCs: The promise and perils of massive open online courses. San Francisco, CA: Parlor Press.

Kucina Softic, S., \& Bekic, Z. (2008). Organizational aspects of supporting e-learning at university level. In Proceedings of 30th International Conference on Information Technology Interfaces (pp. 153-158).

Kuo, Y. C., Walker, A. E., Schroder, K. E. E., \& Belland, B. R. (2014). Interaction, Internet self-efficacy, and self-regulated learning as predictors of student satisfaction in online education courses. The Internet and Higher Education, 20, 35-50.

Leem, J., \& Lim, B. (2007). The current status of e-learning and strategies to enhance educational competitiveness in Korean higher education. International Review of Research in Open and Distance Learning, 8(1): 3.

Lerís, D., Sein-Echaluce, M. L., Hern_andez, M., \& Bueno, C., (2017). Validation of indicators for implementing an adaptive platform for MOOCs. Computers in Human Behavior, 72, 783-795. 
Marshall, S. (2007). e-Learning maturity model: Process descriptions. University Teaching Development Centre, Victoria University of Wellington, New Zealand.

McCarthy, S. A., \& Samors, R. J. (2009). Online learning as a strategic asset: Volume I: A resource for campus leaders. Washington DC: Association of Public and LandGrant Universities.

Mendling, J., Neumann, G., Pinterits, A., Simon, B., \& Wild, F. (2005). Indirect revenue models for e-learning at universities - The case of Learn@WU. In M. H. Breitner \& G. Hoppe (Eds.), E-Learning: Einsatzkonzepte und Geschäftsmodelle (pp. 301-311).

Miller, G., Benke, M., Chaloux, B., Ragan, L., Schroeder, R., Smutz, W., \& Swan, K. (2013). Leading the e-learning transformation of higher education: Meeting the challenges of technology and distance education. Stylus Publishing.

Moeini, A., Kiani, M., \& Mohajerani, M. (2003). Change in Iranian higher education and training system related to information technologies. In Proceedings of the 2nd European Conference on eLearning (ECEL2003) (pp. 347-360).

Mohammadi, H. (2015). Investigating users' perspectives on e-learning: An integration of TAM and IS success model. Computers in Human Behavior, 45, 359-374.

Morer, A. (2008). The integration of information and communication technologies in the university: Models, problems and challenges. Doctoral dissertation, Universitat Rovira i Virgili, Tarragona, Spain. Retrieved from http://www.tonybates.ca/wpcontent/uploads/english_summary_final4.pdf

Nedungadi, P., \& Raman, R. (2012). A new approach to personalization: Integrating elearning and m-learning. Educational Technology Research and Development, 60(4), 659-678.

Ossiannilsson, E. (2012). Benchmarking e-learning in higher education, lessons learned from international projects. Doctoral dissertation, University of Oulu, Finland. Retrieved from http://herkules.oulu.fi/isbn9789526200415/isbn9789526200415.pdf

Peterson, D. (2017). The pros and cons of MOOCS: From Nathan Heller's article, "Laptop U," for The New Yorker. Retrieved from https://www.thoughtco.com/thepros-and-cons-of-moocs-31030

Powell, A. (2011). A case study of e-learning initiatives in New Zealand's secondary schools. Doctoral dissertation, Pepperdine University, USA. Retrieved from https://search.proquest.com/openview/60ace54371624784dd777ca8f67f56c2/1?pqorigsite $=$ gscholar $\& \mathrm{cbl}=18750 \&$ diss $=\mathrm{y}$

Radovic Markovic, M., Salamzadeh, A., Markovic, D., Grozdanic, R., \& Vucekovic, M. (2012). e-Learning in business and entrepreneurship: Evidence from Serbia, Iran, and India. In Proceedings of the 1st Annual International Conference on Employment, Education and Entrepreneurship. Retrieved from http://ssrn.com/abstract=2203718

Raposo-Rivas, M., Martínez-Figueira, E., \& Sarmiento Campos, J. A. (2015). Unestudio sobre los componentes pedag_ogicos de los cursos online masivos. Comunicar, 22(44), 27-35.

Schuwer, R., Gil-Jaurena, I., Aydin, C. H., Costello, E., Dalsgaard, C., Brown, M., ... Teixeira, A. (2015). Opportunities and threats of the MOOC movement for higher education: The European perspective. International Review of Research in Open and Distributed Learning, 16(6), 20-38.

Smith, S. H., Smith, S. H., Samors, R., \& Mayadas, A. F. (2008). Positioning online learning as a strategic asset in the thinking of university presidents and chancellors. Journal of Asynchronous Learning Networks, 12(2), 91-100.

Talebian, S., Movahed Mohammadi, H., \& Rezvanfar, A. (2014). Information and communication technology (ICT) in higher education: Advantages, disadvantages, conveniences and limitations of applying e-learning to agricultural students in Iran. Procedia - Social and Behavioral Sciences, 152, 300-305.

TechNavio. (2014). TechNavio says the global e-learning market will post a CAGR of 
15.06 percent from 2015-2019. Retrieved from https://www.businesswire.com/news/home/20141216005722/en/TechNavio-GlobalE-learning-Market-Post-CAGR-15.06

Teixeira, A., Garcia-Cabot, A., García-Lopez, E., Mota, J., \& de-Marcos, L. (2016). A new competence-based approach for personalizing MOOCs in a mobile collaborative and networked environment. RIED. Revista Iberoamericana de Educación a Distancia, 19(1), 143-160.

University of Tehran Second Plan. (2011). University of Tehran, Planning and Information Technology Vice Presidency. Retrieved from http://ut.ac.ir/Files/barnameye\%20dovom.pdf

UT at a Glance. (2016). University of Tehran. Retrieved from http://ut.ac.ir/en/page/757/ut-at-a-glance

Uysal, I., \& Kosemen, S. (2013). Analysis of the pre-service teachers' general self-esteem beliefs. Journal of Research in Education and Teaching, 2(2), 217-226.

Vignare, K., Geith, C., \& Schiffman, S. (2006). Business models for online learning: An exploratory survey. Journal of Asynchronous Learning Networks, 10(2), 53-67.

Willey, D. (2013). The CCKO8 MOOC connectivism course, 1/4 way. Retrieved from www.davecormier.com/edblog/2008/10/02/the-cck08-mooc-connectivism-course-14way/

Y1lmaz, R., \& Keser, H. (2016). The impact of interactive environment and metacognitive support on academic achievement and transactional distance in online learning. Journal of Educational Computing Research, 55(1), 95-122.

Yilmaz, R. (2017). Exploring the role of e-learning readiness on student satisfaction and motivation in flipped classroom. Computers in Human Behavior, 70, 251-260.

Yin, K. R. (2003). Case study research: Design and methods. Sage Publications.

Young population a golden opportunity. (2014, September 09). Iran Daily. Retrieved from http://www.iran-daily.com/News/1288.html

Zapata-Ros, M. (2013). MOOCs, una visi_on crítica y una alternativa complementaria: La individualizaci_on del aprendizaje y de la ayuda pedag_ogica. Campus Virtuales. Revista Científica Iberoamericana de Tecnología Educativa, 2(1), 20-38. 